\title{
The digestibility in piglets of faba bean (Vicia faba L.) as affected by breeding towards the absence of condensed tannins
}

\author{
BY A. F. B. VAN DER POEL \\ Agricultural University, Department of Animal Nutrition, Haagsteeg 4, 6708 PM Wageningen, \\ The Netherlands \\ AND L. M. W. DELLAERT \\ Agricultural College Delft, PO Box 3190, 2601 DD Delft, The Netherlands \\ AND A. VAN NOREL AND J. P. F. G. HELSPER \\ DLO-Centre of Plant Breeding and Reproduction Research (CPRO-DLO), PO Box 16, \\ 6700 AA Wageningen, The Netherlands
}

(Received 7 April 1991 - Accepted 7 December 1991)

\begin{abstract}
Seed samples from two near-isogenic faba bean (Vicia faba L.) lines were examined for the levels of socalled anti-nutritional factors (ANF). From the ANF known to be present in faba beans, trypsin inhibitor activity, functional lectins, condensed tannins and pyrimidine glycosides were analysed. It was concluded that the lines differed only in the content of condensed tannins being $<0.5 \mathrm{~g} / \mathrm{kg}$ and $5.2(\mathrm{SD} 0.2) \mathrm{g} / \mathrm{kg}$ for the low (LT)- and high (HT)-tannin lines respectively. In addition, the level of pyrimidine glycosides in the LT line was slightly higher than that in the HT line. The LT line showed a reduced proportion of the seed coat $(105 v .119 \mathrm{~g} / \mathrm{kg})$ and a lower seed weight $(0.85 v .1 .01 \mathrm{~g})$. The apparent ileal and faecal digestibility values of dry matter and nitrogen from the HT and LT line were determined for piglets which were fed on diets containing chromium oxide as a marker. The mean apparent ileal and faecal digestibility values for dry matter for the LT line were 0.694 and 0.889 and for $N 0.828$ and 0.879 respectively. For the HT line, these values were approximately 0.05 and 0.10 lower $(P>0.05)$. A multienzyme technique was used to predict the in vitro protein digestibility (IVPD) of the two lines. The IVPD of the LT line was 0.965 and about 0.05 higher than the HT line, confirming the difference in digestibility as measured in vivo. The present study shows the positive effects on digestibility of removal of condensed tannins in faba beans which was achieved by plant breeding.
\end{abstract}

Faba bean: Digestibility: Condensed tannins: Breeding: Piglets

Faba beans (Vicia faba L.) are considered a potential component of diets for singlestomached animals. It has been reported that the growth of pigs given diets containing faba beans is less than expected from their chemical composition (Aherne et al. 1977). This discrepancy becomes apparent with inclusion rates of more than $15 \%$ in the diet while at $40 \%$ severe reduction in performance was observed (Fowler, 1980).

The presence in diets of raw legumes may alter the physiological and metabolic functions due to several anti-nutritional factors (ANF) present in the seeds of Vicia faba L. (Marquardt, 1989). The polyphenolic compounds, particularly the condensed tannins, seem to have a special relevance because of their impact on protein metabolism (Marquardt et al. 1977; Ward et al. 1977; Sobrini et al. 1983). Condensed tannins usually constitute a substantial proportion in faba beans (up to $35 \mathrm{~g} / \mathrm{kg}$, air-dry basis; Cabrera \& Martin, 1986). Nutritional studies have shown that the presence of condensed tannins in the diet of 
non-ruminants may cause adverse biological effects (for review, see Marquardt, 1989). These effects are associated with an astringent taste as well as with the ability of condensed tannins to form complexes with digestible dietary protein or enzymes or with both (Wiseman \& Cole, 1988). The digestibility of crude protein (nitrogen $\times 6.25$ ) of a tannin-free cultivar was reported to be higher than that of a tannin-containing cultivar (Liebert \& Gebhardt, 1983). It is likely that the removal of condensed tannins may improve the nutritional value of faba beans. These compounds are mostly confined to the seed coat and removal, therefore, can be achieved by dehulling (Van der Poel et al. 1991 b) but the financial consequences of processing costs will have to be accounted for. Furthermore, the disposal of hulls may become a problem (Wiseman \& Cole, 1988).

As an alternative to technological methods, breeding for low-tannin content can be considered. Since low tannin content and white flowers are probably controlled by the same gene (Bond \& Smith, 1989), selection of white flowering genotypes may yield low-tannin (LT) faba bean lines.

In the present study near-isogenic lines of Vicia faba L., differing in the absence or presence of condensed tannins, were evaluated. Analytical aspects of other anti-nutritional factors were investigated as well. The effects of inclusion of these two lines in pig diets on the ileal and faecal digestibility of dry matter (DM) and $\mathrm{N}$ were examined. Finally, a multienzyme in vitro technique was used as a more rapid technique to predict bean digestibility.

\section{EXPERIMENTA L}

\section{Breeding}

Near-isogenic lines of Vicia faba L. were derived from a cross between the parental genotypes SVP-78999 $\times$ Staygreen as described previously (Van Loon et al. 1989). The latter genotype produces a tannin-free seed coat. The genotypes differed in anthocyaninbased pigmentation of the petals, one genotype having pigmented flowers and seeds with high level of tannins (HT), the other having white flowers with seeds in which tannins are virtually absent (LT). After continued selfing for six generations a line was isolated which was still heterozygous for flower pigmentation. By selfing and selection during another four successive generations two homozygous near-isogenic lines were produced which differed in the absence or presence of flower pigmentation.

\section{Chemical analyses}

Seeds of the two near-isogenic lines were characterized for the levels of anti-nutritional factors, DM and N. In addition, the seeds were analysed for proportion of seed coat (by manual dissection) and seed weight. For each chemical characteristic in Table 2, four samples of five seeds each were analysed. These samples were taken from the batch that was also used for the animal feeding experiment.

The DM content was determined by drying the samples to constant weight at $101^{\circ}$ and $\mathrm{N}$ was determined by the Kjeldahl method. Crude protein was calculated.

The anti-nutritional factors were analysed according to the following procedures.

Trypsin inhibitor activity (TIA) as described by Kakade et al. (1974) and modified by Helsper \& Van Norel (1991).

Condensed tannins were determined by the vanillin-sulphuric acid assay according to Kuhla \& Ebmeier (1981).

Pyrimidine glycosides (vicine and convicine) were analysed by high-performance liquid chromatography. Extraction with perchloric acid $(50 \mathrm{ml} / \mathrm{l})$ and chromatography were carried out according to Marquardt \& Frohlich (1981) with uridine as an internal standard 
Table 1. Formulation of the basal diet*

\begin{tabular}{lrlr}
\hline \hline \multicolumn{4}{c}{ Ingredients $(\mathrm{g} / \mathrm{kg})$} \\
\hline Maize starch & 456 & $\mathrm{CaCO}_{3}$ & $1 \cdot 9$ \\
Wheat middlings & 50 & $\mathrm{CaHPO} \cdot 2 \mathrm{H}_{2} \mathrm{O}$ & $28 \cdot 6$ \\
Casein & 131 & $\mathrm{NaCl}$ & $3 \cdot 0$ \\
Herring meal & 50 & DL-methionine & $1 \cdot 1$ \\
Cellulose & 21 & L-threonine & $0 \cdot 6$ \\
Soya-bean oil & 29 & L-tryptophan & $0 \cdot 2$ \\
Dextrose & 160 & NaHCO & $12 \cdot 2$ \\
Cane molasses & 40 & $\mathrm{KHCO}_{3}$ & $6 \cdot 4$ \\
VTM & 10 & Marker $\mathrm{Cr}_{2} \mathrm{O}_{3}$ & $1 \cdot 0$ \\
\hline \hline
\end{tabular}

VTM, Vitamin and trace mineral premix (for detailed composition, see Van der Poel et al. 1990 a).

* Chemical analysis $(\mathrm{g} / \mathrm{kg})$ : nitrogen $29 \cdot 7$, fibre 22 , diethyl ether extract 36 , ash 65.

(S. J. M. van Zevenhuizen, personal communication). Briefly, a spherisorb ODS 2 column $(3 \mu \mathrm{m} ; 125 \times 4 \mathrm{~mm}$ ) was used with $0.05 \mathrm{M}$-sodium citrate as the mobile phase ( $\mathrm{pH} 6.95$, at $1.0 \mathrm{ml} / \mathrm{min}) ;$ u.v. absorption at $280 \mathrm{~nm}$ was applied for detection.

Functional lectins of faba beans were analysed by a functional lectin immunoassay (FLIA) using thyroglobulin as a coating in the ELISA. (Hamer et al. 1989).

In vitro protein digestibility (IVPD) was determined according to a modified procedure of Babinszky et al. (1990). In this procedure, samples are incubated with pepsinhydrochloric acid solution at $40^{\circ}$ for $1.5 \mathrm{~h}$. After neutralization with sodium bicarbonate, incubation is continued $\left(40^{\circ} ; 1 \mathrm{~h}\right)$ with potassium phosphate buffer containing hog pancreatine, $\alpha$-amylase (EC 3.2.1.1), lipase $(E C 3.1 .1 .3)$ and bile salts. Following incubation, sodium carbonate is added to stop the reaction. The undissolved material is then filtered on a scintered-glass filter crucible, which was fitted with a layer of $\mathrm{N}$-free ashless floc. The undigested residue and the ashless floc are brought into a Kjeldahl flask for the determination of the $\mathrm{N}$ content by the Kjeldahl method. The digestibility coefficient is calculated by difference from the $\mathrm{N}$ content of the bean sample before digestion.

\section{Animals and procedures}

The apparent ileal and faecal digestibilities of beans were measured by difference from a control diet using five castrated male piglets (crossbred) per treatment. The initial weights at the beginning of the experiments were approximately 22.5 (ileal experiment; fifteen animals) and $24.5 \mathrm{~kg}$ (faecal experiment; fifteen animals). For ileal measurements the animals had been fitted with a post-valvular T-caecum cannula (Van Leeuwen et al. 1988) at a live weight of $10 \mathrm{~kg}$. All animals were housed individually in cages $(900 \times 800 \times 600 \mathrm{~mm})$ at an ambient temperature of $21^{\circ}$.

Both the experiments, carried out simultaneously, consisted of the following three treatments: (1) basal diet (control), (2) $800 \mathrm{~g}$ basal diet $+200 \mathrm{~g}$ faba beans $(\mathrm{HT}) / \mathrm{kg},(3)$ $800 \mathrm{~g}$ basal diet $+200 \mathrm{~g}$ faba beans $(\mathrm{LT}) / \mathrm{kg}$.

A basal diet (for composition, see Table l) was formulated in which dietary protein was supplied mainly by casein and herring meal; chromium oxide was added to each diet for the determination of ileal digesta flow. Ileal chyme was collected throughout $12 \mathrm{~h} / \mathrm{d}$ for $5 \mathrm{~d}$. Faeces were collected continuously for $5 \mathrm{~d}$. The apparent faecal and ileal digestibility coefficients of DM and $\mathrm{N}$ of the diets and of the two bean cultivars were calculated by difference. Adaptation to diets, feeding level, feed administration, digestibility methodology and statistical analyses were as described previously in detail (Van der Poel et al. 1991 a). 
Table 2. Average levels of anti-nutritional factors, physical characteristics, protein content and in vitro protein digestibility (IVPD) of two near-isogenic lines of Vicia faba $L . *$

(Mean values and standard deviations; unless mentioned otherwise, the results are expressed as $\mathrm{g} / \mathrm{kg}$ fresh weight of the total seed)

\begin{tabular}{|c|c|c|c|c|}
\hline \multirow[t]{2}{*}{ Near-isogenic lines ... } & \multicolumn{2}{|c|}{ Low tannin } & \multicolumn{2}{|c|}{ High tannin } \\
\hline & Mean & SD & Mean & SD \\
\hline \multicolumn{5}{|l|}{ Anti-nutritional factors } \\
\hline Condensed tannins & $<0.5$ & - & $5 \cdot 2$ & $0 \cdot 2$ \\
\hline \multicolumn{5}{|l|}{ Trypsin inhibitory activity $\dagger$} \\
\hline Porcine & 1.61 & $0 \cdot 27$ & $1 \cdot 47$ & $0 \cdot 24$ \\
\hline Bovine & $2 \cdot 59$ & $0 \cdot 46$ & $2 \cdot 34$ & 0.34 \\
\hline Vicine plus convicine & $10 \cdot 4$ & $0 \cdot 7$ & $8 \cdot 4$ & $0 \cdot 5$ \\
\hline Functional lectins & $2 \cdot 3$ & $0 \cdot 1$ & 1.9 & $0 \cdot 1$ \\
\hline \multicolumn{5}{|l|}{ Physical characteristics } \\
\hline Seed coat & 105 & 5 & 119 & 5 \\
\hline Seed weight (g) & 0.85 & 0.07 & 1.01 & 0.05 \\
\hline Dry matter & 853 & 1 & 842 & 1 \\
\hline \multicolumn{5}{|l|}{ Protein } \\
\hline Crude protein (nitrogen $\times 6.25$ ) & 325 & 2 & 306 & 1 \\
\hline IVPD & 0.965 & $0 \cdot 002$ & 0.909 & 0.003 \\
\hline
\end{tabular}

* For details of procedures, see pp. 794-796.

$\dagger$ Trypsin inhibited (mg).

The apparent digestibilities of the faba beans alone (inclusion level of $200 \mathrm{~g} / \mathrm{kg}$ ) were calculated from the difference in digestibility between the control and experimental diets $(800 \mathrm{~g}$ basal diet $+200 \mathrm{~g}$ faba beans $/ \mathrm{kg})$, respectively. For the calculation of digestible DM the following equation was used:

$$
\mathrm{AD}_{\text {DM-faba beans }}=\left(100 \times \mathrm{AD}_{\text {DM-expt diet }}-80 \times \mathrm{AD}_{\mathrm{DM}-\text { basal diet }}\right) / 20 \text {, }
$$

where $\mathrm{AD}$ is the apparent ileal or faecal digestibility of the nutrient under investigation. It can be calculated, however, that the beans contribute $30 \cdot 4 \%$ (LT) and $29 \cdot 2 \%$ (HT) to the $\mathrm{N}$ content of the experimental diets. For calculating digestible $\mathrm{N}$, therefore, extrapolation was based on a mean value of $30 \%$ using the equation:

$$
\mathrm{AD}_{\mathrm{N}-\mathrm{faba} \text { beans }}=\left(100 \times \mathrm{AD}_{\mathrm{N}-\text { expt diet }}-70 \times \mathrm{AD}_{\mathrm{N}-\text { basal diet }}\right) / 30 \text {. }
$$

The statistical analyses of data were performed with the ANOVA procedure of the Statistical Analysis System (SAS, 1985), followed by the Student's $t$ test.

\section{RESULTS}

Characterization of near-isogenic lines

The results of the physical and chemical characterization of the faba bean lines are presented in Table 2. The LT line showed a reduced proportion of seed coat as well as a lower seed weight. Tannin analyses demonstrated that the LT line contained negligible levels of condensed tannins in contrast to the HT line. The two lines did not differ in TIA with porcine as well as bovine trypsin. The level of vicine plus convicine was about $2 \mathrm{~g} / \mathrm{kg}$ higher in the LT line, while functional lectins were $0.4 \mathrm{~g} / \mathrm{kg}$ higher in the LT line.

IVPD was distinctly different for the two bean lines where, in general, the range of IVPD 
Table 3. Ileal and faecal digestibility values for dry matter $(D M)$ and nitrogen for faba bean (Vicia faba L.) diets containing two near-isogenic lines (low tannin and high tannin) studied in piglets*

(Mean values with their standard errors for five animals per treatment)

\begin{tabular}{|c|c|c|c|c|c|c|c|c|}
\hline \multirow[b]{3}{*}{ Diet } & \multicolumn{4}{|c|}{ Ileal } & \multicolumn{4}{|c|}{ Faecal } \\
\hline & \multicolumn{2}{|c|}{$\mathrm{DM}$} & \multicolumn{2}{|c|}{$N$} & \multicolumn{2}{|c|}{$\mathrm{DM}$} & \multicolumn{2}{|c|}{$\mathrm{N}$} \\
\hline & Mean & SE & Mean & SE & Mean & $\mathrm{SE}$ & Mean & $\mathrm{SE}$ \\
\hline Control & $0 \cdot 862^{\mathrm{a}}$ & 0.018 & $0.818^{a}$ & $0-021$ & $0.927^{\mathrm{a}}$ & 0.013 & $0.935^{a}$ & 0.014 \\
\hline \multicolumn{9}{|l|}{ Experimental } \\
\hline Low tannin & $0 \cdot 828^{\mathrm{b}}$ & 0.013 & $0 \cdot 820^{\mathrm{a}}$ & $0 \cdot 015$ & $0.919^{a}$ & 0.009 & $0.932^{\mathrm{a}}$ & 0.008 \\
\hline High tannin & $0 \cdot 816^{\mathrm{b}}$ & 0.011 & $0.799^{\mathrm{a}}$ & 0.012 & $0.908^{\mathbf{a}}$ & 0.009 & $0.920^{a}$ & 0.020 \\
\hline
\end{tabular}

a, b Values with different superscript letters within the same column differed significantly $(P<0.05)$.

* For details of procedures, see pp. $794-796$.

Table 4. Ileal and faecal digestibility values for dry matter $(D M)$ and nitrogen for two near-isogenic lines (low tannin and high tannin) of faba bean (Vicia faba L.) studied in piglets*

(Mean values with their standard errors for five animals per treatment; the digestibility coefficients of the faba bean lines were calculated by difference from the control diet)

\begin{tabular}{|c|c|c|c|c|c|c|c|c|}
\hline & \multicolumn{4}{|c|}{ Ileal } & \multicolumn{4}{|c|}{ Faecal } \\
\hline & \multicolumn{2}{|c|}{ DM } & \multicolumn{2}{|c|}{$\mathrm{N}$} & \multicolumn{2}{|c|}{ DM } & \multicolumn{2}{|c|}{$\mathbf{N}$} \\
\hline & Mean & SE & Mean & $\mathrm{SE}$ & Mean & SE & Mean & $\mathrm{SE}$ \\
\hline Low tannin & 0.694 & $0 \cdot 030$ & 0.829 & 0.034 & 0.889 & 0.021 & 0.879 & 0.017 \\
\hline High tannin & 0.634 & 0.024 & 0.724 & 0.026 & 0.834 & 0.021 & 0.820 & 0.023 \\
\hline
\end{tabular}

* For details of procedures, see pp. 794-796.

values of feedstuffs is rather small. The highest in vitro digestibility was observed for the LT line.

\section{Digestibility of near-isogenic lines}

The effects of addition of both faba bean lines, LT and HT, to a control diet on apparent digestibility coefficients are presented in Tables 3 and 4 . The faba bean diets (Table 3 ) showed an ileal digestibility of DM which was 0.034 (LT) and 0.046 (HT) lower in comparison with the control diet $(P<0.05)$. When the control diet and the faba bean lines alone (calculated by difference from the control diet; Table 4) are compared, the decreases in ileal digestibility of DM were 0.168 (LT) and 0.228 (HT), respectively. $\mathrm{N}$ digestibilities of the experimental and control diets were similar. Calculation of faba bean digestibility revealed that the ileal $\mathrm{N}$ digestibility of the HT line was lower compared with the LT line $(P>0.05)$. Values were 0.829 for LT and 0.724 for HT beans respectively.

Faecal digestibility of LT and HT faba bean diets (DM) differed slightly, but not significantly, from the control diet by 0.008 and 0.019 respectively (Table 3). Faecal digestibility of DM differed by about $0.055(P>0.05)$ for the two faba bean lines. For $\mathrm{N}$ the faecal digestibility of LT and HT diets differed by 0.003 and 0.015 respectively from the 
control diet. Calculation of the faecal digestibility of the faba bean lines alone resulted in digestibility values for $\mathrm{N}$ which were 0.056 (LT line; $P>0.05$ ) and 0.115 (HT line; $P>0.05$ ) lower than that of the control diet.

\section{DISCUSSION}

The digestibility of legumes as feed ingredients will be influenced by the presence of a number of ANF such as condensed tannins, lectins, trypsin inhibitor activity and pyrimidine glycosides (Bond \& Smith, 1989; Liener, 1989). The objective of the present study was to evaluate the effect of condensed tannins on digestion of faba beans in piglets. For this purpose a pair of near-isogenic lines of Vicia faba L. was produced by classical breeding which differed in the presence (HT line) or absence (LT line) of condensed tannins. The higher digestibility values of DM $(0.05)$ and $\mathrm{N}(0 \cdot 10)$ of the LT line observed in the present study $(P>0.05)$ can be attributed mainly to the lack of condensed tannins, although a minor effect of the lower proportion of fibrous seed-coat material (105 $v$. $199 \mathrm{~g} / \mathrm{kg}, 1.4 \%$ ) has also to be taken into account.

The multi-enzyme technique used to determine the IVPD also showed a higher value for the LT line in comparison with the HT line. The absolute IVPD values are higher than the in vivo values. The latter observation is inherent with in vitro procedures (Babinszky et al. 1990).

The conclusion that the difference in digestibility is due to the difference in tannins is only valid when the near-isogenic lines do not differ in constituents other than condensed tannins. Analysis of the main anti-nutritional or toxic factors, or both, revealed, besides the difference in condensed tannins, only minor differences between the near-isogenic lines.

It is unlikely that the higher levels of lectins and pyrimidine glycosides in the LT line will result in a higher digestibility.

The tannin content of the HT line is of the same order of magnitude as that of commercially available genotypes of Vicia faba L. The levels of functional lectin and of TIA found are considered relatively high for both lines. This high level might be a cause for the relatively low absolute level of DM digestibility. However, the relative contribution of these ANF to the overall effects on digestibility has not yet been established.

In removing the condensed tannins genetically, one has to consider the possible simultaneous consequences on agronomic characteristics like resistance to disease and tolerance for adverse weather conditions. It was shown that the plant resistance to root rot damage of the white-flowering (LT) line was equal to that of the HT line with pigmented flowers (Van Loon et al. 1989; Helsper \& Van Norel, 1991). However, the seedling emergence under conditions of cold stress was significantly lower for the LT line.

The standard method for measuring apparent digestibility in pigs (difference method) may be criticized due to the methodology of replacing a part of the basal diet by the feedstuff which has to be examined. In this way, a possible interaction of components (e.g. ANF) in the feedstuff with the basal diet is not taken into account. It is notable that if an interaction is present this may lead to an under- or overestimation of the digestibility coefficients. The presence of tannins in the gastrointestinal tract may induce complexes with dietary protein or digestive enzymes, or both, thereby reducing the digestibility of the protein (Marquardt, 1989). Also, possible interactions between tannins and proteins in the basal diet or between tannins and the mucosa of the intestinal wall (M. J. L. Kik, unpublished results) may lead to an increased secretion of endogenous protein. These phenomena may explain the observed reduction in DM and $\mathrm{N}$ digestibility of the HT line in the present experiment.

For a further comparison of the nutritional value of both lines the investigation has to 
include the effect on digestibility of starch and non-starch polysaccharides, because an interaction was reported for the digestibility of nutrients of faba bean for chicken (Lacassagne et al. 1988).

Finally, a technological and more practical implication is the ease with which dry beans from the LT cultivar could be ground by comparison with the HT line. This is probably due to a more fragile seed coat of the LT line.

The authors thank S. J. M. van Zevenhuizen (Agrotechnological Research Institute, Wageningen) for the development of the high-performance liquid chromatographic procedure used in the quantitative analysis of vicine and convicine. Also, they are grateful to J. Blonk for animal care and collection of ileal chyme and faeces.

\section{REFERENCES}

Aherne, F. X., Lewis, A. J. \& Hardin, R. T. (1977). An evaluation of faba beans (Vicia faba) as a protein supplement for swine. Canadian Journal of Animal Science 57, 321-326.

Babinszky, L., Van der Meer, J. M., Boer, H. \& Den Hartog, L. A. (1990). An in vitro method for prediction of the digestible crude protein content in pig feeds. Journal of the Science of Food and Agriculture 50, 173-178.

Bond, D. A. \& Smith, D. B. (1989). Possibilities for the reduction of antinutritional factors in grain legumes by breeding. In Recent Advances of Research in Antinutritional Factors in Legume Seeds, pp. 285-296 [J. Huisman, A. F. B. van der Poel and I. E. Liener, editors]. Wageningen: Pudoc.

Cabrera, A. \& Martin, A. (1986). Variation in tannin content in Vicia faba L. Journal of Agricultural Science, Cambridge 106, 377-382.

Fowler, V.F. (1980). The value of field beans (Vicia faba L.) and other legumes for the feeding of pigs. In Vicia faba: Feeding Value, Processing and Viruses, pp. 31-41 [D. A. Bond, editor]. The Hague: Martinus Nijhoff.

Hamer, R. J., Koninkx, J., Van Oort, M., Mouwen, J. M. V. M. \& Huisman, J. (1989). New developments in lectin analysis. In Recent Advances of Research in Antinutritional Factors in Legume Seeds, pp. 30-33 [J. Huisman, A. F. B. van der Poel and I. E. Liener, editors]. Wageningen: Pudoc.

Helsper, J. P. F. G. \& Van Norel, A. (1991). Antinutritional factors in faba bean and resistance to soil-borne diseases. In Biotic Interactions and Soil-borne Diseases, pp. 387-391 [A. B. R. Beemster, G. J. Bollen, M. Gerlagh, M. A. Ruissen, B. Schippers and A. Tempel, editors]. Amsterdam: Elsevier Science Publishers.

Kakade, M. L., Rackis, J. J., McGhee, J. E. \& Puskai, G. T. (1974). Determination of trypsin inhibitor activity of soy products: a collaborative analysis of an improved procedure. Cereal Chemistry 51, 376-382.

Kuhla, S. \& Ebmeier, C. (1981). Untersuchungen zum Tanningehalt in Ackerbohnen (Research into the levels of tannins in faba beans). Archiv für Tierernährung 31, 573-588.

Lacassagne, L., Francesch, M., Carre, B. \& Melcion, J. P. (1988). Utilization of tannin-containing and tannin-free faba beans (Vicia faba) by young chicks: effects of pelleting feeds on energy, protein and starch digestibility. Animal Feed Science and Technology 20, 59-68.

Liebert, F. \& Gebhardt, G. (1983). Ergebnisse der vergleichenden ernährungsphysiologischen Prüfung verschiedener Ackerbohnenherkunfte am Mastschwein unter besonderer Beachtung einer weissblühenden Neuzuchtung (Nutritional evaluation in pigs of different varieties of faba beans, particularly a new whiteflowering variety). Archiv für Tierernährung 33, 47-56.

Liener, I. E. (1989). Antinutritional factors in legume seeds: state of the art. In Recent Advances of Research in Antinutritional Factors in Legume Seeds, pp. 6-13 [J. Huisman, A. F. B. van der Poel and I. E. Liener, editors]. Wageningen: Pudoc.

Marquardt, R. R. (1989). Dietary effects of tannins, vicine and convicine. In Recent Advances of Research in Antinutritional Factors in Legume Seeds, pp. 141-155 [J. Huisman, A. F. B. van der Poel and I. E. Liener, editors]. Wageningen: Pudoc.

Marquardt, R. R. \& Frohlich, A. A. (1981). Rapid reversed-phase high-performance liquid chromatographic method for the quantitation of vicine, convicine and related compounds. Journal of Chromatography 208, 373-379.

Marquardt, R. R., Ward, A. T., Campbell, L. D. \& Cansfield, P. E. (1977). Purification and characterization of a growth inhibitor in faba beans (Vicia faba L.). Journal of Nutrition 106, 275-284.

SAS (1985). Statistical Analysis System. Cary, NC: SAS Institute Inc.

Sobrini, F. J., Martinez, J. A., Ilundain, A. \& Larralde, J. (1983). The effects of Vicia faba L. polyphenols on absorption, growth and metabolism in the rat. Qualitas Plantarum. Plant Foods for Human Nutrition 33, 231-235.

Van der Poel, A. F. B., Blonk, J., Huisman, J. \& Den Hartog, L. A. (1991a). Effect of steam processing temperature and time on the protein nutritional value of Phaseolus vulgaris beans for swine. Livestock Production Science 28, 305-319. 
Van der Poel, A. F. B., Gravendeel, S. \& Boer, H. (1991 b). Effect of different processing methods on tannin content and in vitro protein digestibility of faba bean (Vicia faba L.). Animal Feed Science and Technology 33, 49-58.

Van Leeuwen, P., Huisman, J., Verstegen, M. W. A., Van Kleef, D. J., Van Weerden, E. J. \& Den Hartog, L. A. (1988). A new technique for collection of ileal chyme in pigs. Proceedings of the IVth International Seminar on Digestive Physiology in the Pig, pp. 289-296 [L. Buraczewska, S. Buraczewski, B. Pastuszewska and T. Zebrowska, editors]. Warsaw: Polish Academy of Sciences.

Van Loon, J., Van Norel, A. \& Dellaert, L. M. W. (1989). Tannin-free Vicia faba L. and disease resistance: conflicting breeding objectives? In Recent Advances of Research in Antinutritional Factors in Legume Seeds, pp. 301-304 [J. Huisman, A. F. B. van der Poel and I. E. Liener, editors]. Wageningen: Pudoc.

Ward, A. T., Marquardt, R. R. \& Campbell, L. D. (1977). Further studies on the isolation of the thermolabile growth inhibitor from the faba bean (Vicia faba, L. var. minor). Journal of Nutrition 107, 1325-1334.

Wiseman, J. \& Cole, D. J. A. (1988). European legumes in diets for non-ruminants. In Recent Advances in Animal Nutrition, pp. 13-37 [W. Haresign and D. J. A. Cole, editors]. London: Butterworths. 